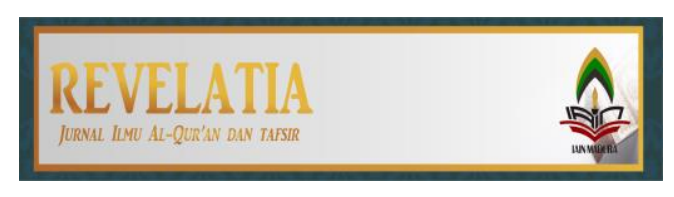

\title{
STUDI MAQÂSHID AL-QUR'ÂN SURAH AL-NISÂ': 1-5 MENURUT SHIDDÎQ HASAN KHÂN DALAM KITAB FATH AL-BAYÂN FÎ MAQÂSHID AL-QUR'ÂN
}

\author{
Ahmad Khoiri \\ Sekretaris Redaksi harakatuna.com, \\ Email:achkhoirie9@gmail.com
}

\begin{abstract}
Abstrak:
Penelitian ini bertujuan untuk mengungkap maqâshid al-Qur'ân menurut Hasan Khân. Karena luasnya medan penelitian, penulis mengambil sampel sebagai spesifikasi, yaitu surah alNisâ'[4]: 1-5. Spesifikasi tersebut dipakai penulis untuk menelisik maqâshid al-Qur'ân menurut Hasan Khân dari tiga aspek: ontologis, epistemologis, dan aksiologis. Penelitian ini menggunakan metode deskriptif-analitis, yakni mendeskripsikan penafsiran Hasan Khân, serta menganalisis konsep maqâshid al-Qur'ân dalam tafsirnya. Ada tiga rumusan masalah utama dalam penelitian ini: apa maksud maqâshid al-Qur'ân menurut Shiddîq Hasan Khân, bagaimana aplikasi metodologisnya, serta apa implikasi dari konsep maqâshid al-Qur'ân menurut Shiddîq Hasan Khân dalam tafsir Fath al-Bayân fî Maqâshid al-Qur'ân surah al-Nisâ' [4]: 1-5. Melalui penelitian ini, lanskap maqâshid al-Qur'ân menurut Hasan Khân teruraikan, tidak hanya penafsirannya terhadap surah al-Nisâ' [4]: 1-5 memuat disiplin maqâshid, namun juga keterlibatan Hasan Khân terhadap spektrum dinamika maqâshid, serta sumbangsih Hasan Khân terhadap diskursus maqâshid al-Qur'ân.
\end{abstract}

Kata Kunci: Aksiologi; Epistemologi; Maqâshid al-Qur'ân; Ontologi

\section{PENDAHULUAN}

Diskursus maqâshid al-Qur'ân merupakan diskursus yang paling digeluti dewasa ini. ${ }^{1}$ Ia menjadi bidang kajian dengan daya pikat khas, yang membuat perhatian para sarjana alQur'an tertuju padanya. Dalam rentang sejarah pemikiran keislaman, terutama hal ihwal penafsiran, maqâshid al-Qur'ân memiliki rekam jejak yang teramat panjang mulai era klasik hingga era kontemporer. ${ }^{2}$ Di era klasik, seorang ulama asal India memiliki pandangan yang sama sekali berbeda ketika mengartikan maksud-maksud (maqâshid) tersebut. Ia dikenal dengan Shiddîq Hasan Khân (1832-1890), cendekiawan produktif abad ke-19. Melalui magnum opus-nya, Fath al-Bayân fì Maqâshid al-Qur'ân, ${ }^{3}$ Hasan Khân memberi ragam baru makna Kitab Suci. Proyek tafsirnya dinarasikan sebagai tafsir terbaik; bebas dari kisah-kisah

\footnotetext{
1 Selama lima dekade terakhir, diskursus maqâshid al-Qur'ân mengalami perkembangan yang signifikan dan menjadi pondasi metodologis paling digemari dalam ijtihad kontemporer. Lihat, misalnya, 'Abd al-Raḩmân Halalî, "Muqârabât Maqâshid al-Qur'ân al-Karîm; Dirâsah Târikhiyyah," AlTajdîd, vol. 20, no. 39, (2016), hlm. 194.

2 Pemilahan 'klasik' dan 'kontemporer' di sini didasarkan perbedaan signifikan antara keduanya, baik secara epistemologis maupun aksiologisnya. Namun, secara ontologis, keduanya sama: istilah untuk bagian terdalam al-Qur'an, yakni substansi nas, dengan proyek ke arah perbaikan (al-ishlâh). Dinamika klasik-kontemporer diulas lengkap, di antaranya dalam, Ibid., hlm. 195-223.

${ }^{3}$ Shiddîq Hasan Khân, Fath al-Bayân fî Maqâshid al-Qur'ân; Tafsîr Salafîy Atsariîy Khâlin min alIsrấn̂liyyât wa al-Jadaliyyât al-Madzhabiyyah wa al-Kalâmiyyah Yughnî 'an Jamî' al-Tafâsîr wa Lâ Tughnî Jamî'uhâ 'Anhu, (Beirut: Al-Maktabah al-'Ashriyyah, t.t.)
} 
isrấîliyyât, perdebatan antarmazhab dan teologi, sehingga diorbitkan sebagai tafsir yang mencakup seluruh hasil penafsiran dan tafsir-tafsir lain tidak bisa setara dengannya. ${ }^{4}$ Sebagai ulama tersohor di abad ke-19, tentu kekhasan konsep maqâshid al-Qur'ân ala Hasan Khân sangat menarik dikaji. Tidak sekadar karena kekhasan konsep, era ia hidup, yakni abad ke-19 yang merupakan era modern dalam sejarah pemikiran Islam menjadi daya pikat tersendiri untuk mengkaji Hasan Khân dan konsep maqâshid al-Qur'ân-nya.

Penelitian ini berusaha untuk mengkaji konsep maqâshid al-Qur'ân perspektif Hasan Khân dalam kitabnya, Fath al-Bayân fî Maqâshid al-Qur'ân, dengan mengambil penafsirannya secara spesifik terhadap surah al-Nisâ' [4]: 1-5. Penelitian ini merupakan kajian tematik tokoh, maka seyogianya penulis juga memaparkan latar belakang Hasan Khân sehingga memberikan gambaran akan keunikan pemikirannya. Bagaimana pun, seperti dikatakan Ulya Fikriyati, "Adalah sebuah aksioma bahwa setiap 'pembaca' teks akan diwarnai oleh horizon yang dimiliki, baik latar ideologis, politik, pendidikan, atau bahkan ekonomi." 5 Sekalipun maqâshid al-Qur'ân dapat diartikan sebagai klimaks penyingkapan makna al-Qur'an, dan tinggal melakukan kontekstualisasi pada setiap zaman, namun sakralitas al-Qur'an di satu sisi serta kesenjangan hierarkis mutakalim dan mukhâthab-seperti dipaparkan di muka-di sisi lainnya menjadikan maksud-maksud tersebut tak pernah usang dikaji.

Klaim tentatifitas penafsiran memang ada, namun klaim kesempurnaan penafsiran (baca: upaya pencarian maksud-maksud al-Qur'an) juga tak kalah mengemuka. Dengan kajian yang komprehensif terhadap konsep maqâshid al-Qur'ân Shiddîq Hasan Khân, diskursus maqâshid al-Qur'ân yang menjadi menu utama para pengkaji al-Qur'an era kontemporer akan menemukan titik terang. Baik menurut kalangan ulama klasik maupun ulama kontemporer, maqâshid al-Qur'ân akan terpahami secara inheren dalam diskursus maqâshid itu sendiri. Dan yang paling penting, melalui penelitian ini akan mengemuka kegigihan upaya Hasan Khân dalam penafsiran al-Qur'an, dalam terang turbulensi sosio-religio-kultural India yang inheren dalam dirinya.

Hasan Khân bernama nasab Abû Thayyib Muhammad Shiddîq ibn Hasan ibn Luthf Allâh. Ia lahir pada 14 Oktober 1832 M/19 Jumadil Ula 1248 H di Berlhi, dan meninggal pada 29 Jumadil Akhir 1307 H/1890 M dalam usia 59 tahun 3 bulan 6 hari.6 Perjalanan karir intelektualnya panjang, dan pengabdiannya terhadap ilmu al-Qur'an dibuktikan dengan karya tafsir yang akan diulas ini. Ketika ulama kontemporer seperti Jasser Auda dan Abdul Karîm Hâmidî baru menekuni diskursus maqâshid al-Qur'ân, dan itupun masih dalam literatur yang terbatas, jauh di masa lalu ternyata telah ada karya terkait yang, menariknya, terdapat ketidaksamaan. Barangkali itu adalah konsekuensi dinamika diskursus maqâshid al-Qur'ân, tetapi jelas menjadi sisi menarik terhadap ulasan komprehensif diskursus itu sendiri.

\footnotetext{
${ }^{4}$ Ini didasarkan anak judul tafsir Fath al-Bayân, bahwa kitab tersebut merupakan "tafsir salaf yang autentik, bebas dari kisah isrấ ̂́liyyât dan perdebatan antarmazhab dan kalam, mencakup seluruh kitab tafsir dan belum tentu selainnya mampu menyamai cakupannya (tafsîr salafîy atsarîy khâlin min alIsrấîliyyât wa al-jadaliyyât al-madzhabiyyah wa al-kalâmiyyah yughnî 'an jamî' al-tafâsîr wa lâ tughnî jamî'uhâ 'anhu)."

5 Ulya Fikriyati, "Maqâshid al-Qur'ân dan Deradikalisasi Penafsiran dalam Konteks Keindonesiaan," Islamica: Jurnal Studi Keislaman, vol. 9, no. 1, (September 2014), hlm. 245.

6 'Abd al-Razzâq al-Dulaymî, Shiddîq Hasan Khân al-Qinnûjîl.., (Riyadh: Al-Tawbah, 2014), hlm. 37; Muhammad Mahdî 'Alî al-Hamûdî, Al-Qannûjî̀ wa Arâ'uhû al-Tafsîriyyah 'alâ Dhaw' Aqwâl Aimmat alTafsîr, (Sudan: Wizârat al-Ta'lîm al-'Âli wa al-Bahts al-'Ilmi, 2015), hlm. 7.
} 
Berdasarkan latar belakang tersebut, artikel ini berusaha menjawab tiga rumusan masalah utama: apa yang dimaksud maqâshid al-Qur'ân menurut Shiddîq Hasan Khân, bagaimana aplikasi metodologis maqâshid al-Qur'ân dalam tafsir Fath al-Bayân fî̀ Maqâshid al-Qur'ân surah al-Nisâ' [4]: 1-5, serta apa implikasi dari konsep maqâshid al-Qur'ân menurut Shiddîq Hasan Khân dalam tafsir Fath al-Bayân fî Maqâshid al-Qur'ân surah al-Nisâ' [4]: 1-5.

Penelitian ini menggunakan pendekatan kualitatif dengan jenis analisis isi (content analysis) terhadap kitab Fath al-Bayân fî Maqâshid al-Qur'ân surah al-Nisâ' [4]: 1-5. Selain itu, jika mengacu terhadap klasifikasi lima jenis penelitian ilmu al-Qur'an dan tafsir menurut Abdul Mustaqim, ${ }^{7}$ maka penelitian ini termasuk ke dalam jenis penelitian tokoh. Penentuan Shiddîq Hasan Khân sebagai objek penelitian ini disebabkan pengaruh dan keunikan pemikirannya tentang maqâshid al-Qur'ân. ${ }^{8}$ Sumber data penelitian ini ada dua, yaitu sumber primer dan sekunder. Sumber data primernya adalah tafsir Shiddîq Hasan Khân sendiri yang berjudul Fath al-Bayân fỉ Maqâshid al-Qur'ân. Sementara sumber sekunder penelitian ini mencakup semua tulisan tentang topik terkait atau yang secara implisit memiliki arah kajian yang sama, baik dikutip dari artikel jurnal, buku, disertasi, majalah, atau dalam sumbersumber lainnya. Di antara yang paling lengkap dari sumber sekunder ini adalah buku Shiddîq Hasan Khân al-Qunûjî̀: Juhûduhû fî Tafsîrihî Fath al-Bayân fî Maqâshid al-Qur'ân karya 'Abd alRazzâq al-Dulaymî. ${ }^{9}$

Metode yang dipakai penulis adalah metode dekripsi-analitis, mengungkap konsep maqâshid al-Qur'ân menurut Shiddîq Hasan Khân lalu memetakannya berdasarkan lanskap diskursus maqâshid al-Qur'ân. Sebagai anak zaman, ia tidak bisa sama sekali dilepaskan dari konteks yang melingkupi dirinya, baik realitas sosial maupun pemahaman keagamaannya. Lokalitas tersebut menjadi daya pikat tersendiri ketika bersentuhan dengan maqâshid alQur'ân, esensi al-Qur'an. Analisis terhadap konstruksi pemikiran Hasan Khân tersebut termanifestasikan dalam kitabnya, Fath al-Bayân fí Maqâshid al-Qur'ân, dan secara spesifik penelitian ini mengacu pada penafsiran Hasan Khân dalam surah al-Nisâ' [4]: 1-5.

Secara teoretis dinamika maqâshid adalah keniscayaan. Maqâshid mulanya berkisar dalam ayat-ayat hukum, hikmah dari sebuah pensyariatan, ${ }^{10}$ lalu tujuan akhir di balik syariat tersebut merupakan objek perhatian para pengkaji al-Qur'an terutama pengkaji maqâshid. Ketika kemaslahatan sifatnya relatif sesuai konteks waktu dan tempat, maka ia berbeda

\footnotetext{
${ }^{7}$ Ada lima jenis penelitian ilmu al-Qur'an dan tafsir menurut Abdul Mustaqim, yaitu penelitian tokoh (al-bahth fî rijâl al-tafsîr), penelitian tematik (al-dirâsat al-mawdhu'iyyah), penelitian manuskrip (philology), dan penelitian living Qur'an. Lihat Abdul Mustaqim, Metode Penelitian al-Qur'an dan Tafsir, cet. ke-1, (Yogyakarta: Idea Press, 2015), hlm. xiii-iv.

8 Abdul Mustaqim juga merumuskan beberapa pertimbangan dalam uji kelaikan penelitian tokoh, yakni sebab popularitas, pengaruh, kontroversi, keunikan, intensitas serta relevansi dan kontribusi tokoh yang akan dikaji. Selengkapnya lihat, Ibid., hlm. 37-40.

9 Dulaymî, Shiddîq Hasan Khân al-Qannûîí; Juhûduh fî Tafsîrih.

${ }^{10}$ Secara prinsipil, menurut al-Raysûnî, dalam sebuah persyariatan (tasyrî) terdapat klimaks makna yang mesti dicapai seorang mukalaf. Syariat menginginkan agar orang mukalaf berupaya mencapai apa yang dimaksudkan syâri' dan berusaha terhadap apa yang ditujukan olehnya. Lihat Ahmad al-Raysûnî, Madkhal ilâ Maqâshid al-Syarî‘ah, (Kairo: Dâr al-Kalimah li al-Nasyr wa al-Tawzî', 2010), hlm. 7.
} 
secara implementatif dalam setiap keadaan. ${ }^{11}$ Alternatifnya ialah dengan geliat kajian tentang maqâshid, berawal dari geliat maqâshid al-syarî'ah dan menjadi maqâshid al-Qur'ân. ${ }^{12}$

\section{Maqâshid al-Qur'ân Menurut Hasan Khân; Kajian Ontologis}

Sebagai sebuah diskursus, maqâshid al-Qur'ân bertransformasi menjadi sebuah ilmu, yakni ilmu tentang esensi ajaran al-Qur'an. Oleh karena aktivitas ilmu bergerak dalam tiga pertanyaan substansial: apakah yang ingin diketahui, bagaimana cara memperolehnya dan apakah nilainya, maka ilmu itu juga tidak dapat bebas dari landasan ontologis, epistemologis, dan aksiologis. ${ }^{13}$ Ontologi14 merupakan sinonim metafisik, yaitu studi tentang wujud seperti karakteristik dasar dari seluruh realitas dan makna sebuah eksistensi. ${ }^{15}$ Landasan ontologis berusaha mengadakan penyelidikan terhadap sifat dan realitas dengan refleksi rasional serta analisis sintesis-logik. ${ }^{16}$ Meskipun terdapat perbedaan mendasar antara pemikiran filosofis dan ilmu-ilmu keagamaan, seperti dikatakan oleh Khudori Soleh, ${ }^{17}$ namun titik tekan kajian ontologis di sini ialah memahami hakikat-metafisik maqâshid al-Qur'ân dalam pemikiran Hasan Khân. Tentu saja hal itu ditempuh dengan menguraikan penafsirannya terhadap surah al-Nisâ' [4]: 1-5, sebagai tolok ukur mengetahui sisi ontologisnya.

Penting untuk dicatat bahwa maqâshid al-Qur'ân mulanya diperoleh dengan menafsirkan al-Qur'an. Artinya, maqâshid al-Qur'ân setua usia penafsiran itu sendiri. Sebab, sejatinya tafsir adalah upaya mencari maksud-di situ terdapat kesamaan visi dengan maqâshid al-Qur'ân, atau bahkan maqâshid itulah substansi ajaran al-Qur'an. Jika demikian adanya, maka maqâshid al-Qur'ân juga bersifat dinamis dan tidak lepas dari konteks sosialkebudayaan tertentu. Itu karena akselerasi konstruk sosial-budaya selalu memengaruhi

11 Muhammad Habîb ibn al-Hujah, Maqâshid al-Syarî́ah al-Islâmiyyah li Syaykh al-Imâm al-Akbar Muhammad Thâhir bin 'Âsyûr, jilid 3, (Qatar: Thab'ah Wizârat al-Awqâf wa al-Syu'ûn al-Islâmiyyah, 2004), hlm. 111.

${ }^{12}$ Argumen normatif tentang adanya maqâshid banyak dipaparkan al-Qur'an, seperti dalam surah alAnbiyâ' [21]: 16, al-Dukhân [44]: 38, dan al-Mu'minûn [23]: 119. Lihat, Ibid., hlm. 35. Maqâsshid alsyarî́ah pun menjadi isu lama yang tak pernah selesai dikaji. Seiring dinamika studi al-Qur'an, akumulasi hikmah dalam hukum-hukum syariat itu kemudian menjadi dasar dari munculnya diskursus maqâshid al-Qur'ân.

${ }^{13}$ Bahrum, "Ontologis, Epistemologi dan Aksiologi," Sulesana, vol. 8, no. 2, 2013, hlm. 35-6.

${ }^{14}$ Hakikat kenyataan secara ontologis dapat didekati melalui dua sudut pandang, yakni kuantitatif dan kualitatif. Istilah penting dalam bidang ontologi di antaranya: yang ada (being), eksistensi (existence), esensi (essence), dan substansi (substance). Selengkapnya lihat T. M. Soerjanto Poespowardojo dan Alexander Seran, Filsafat Ilmu Pengetahuan: Hakikat Ilmu Pengetahuan, Kritik Terhadap Visi Positivisme Logis, serta Implikasinya, cet. ke-2, (Jakarta: Kompas, 2015), hlm. 30. Dalam konteks penelitian ini, penulis hendak menguraikan maqâsshid al-Qur'ân menurut Hasan Khân secara ontologis, yakni esensi pemikirannya tentang maqâshid.

15 Almasdi Syahza, "Filsafat Ilmu: Ontologis, Epistemologi, Aksiologi," power point dalam http://almasdi.unri.ac.id (diakses pada 6 April 2019)

${ }^{16}$ Musa Asy'ari, "Filsafat Islam Suatu Tinjauan Ontologis," sebagaimana dikutip oleh Abdul Mustaqim, Dinamika Sejarah Tafsir al-Qur'an; Studi Aliran-aliran Tafsir dari Periode Klasik, Pertengahan hingga Modern-Kontemporer, cet. ke-2 (Yogyakarta: Idea Press. 2016), hlm. 115.

${ }^{17}$ Khudori Soleh, Filsafat Islam dari Klasik hingga Kontemporer, cet. Ke-1, (Yogyakarta: Ar-Ruzz Media, 2016), hlm. 36. 
dunia penafsiran.18 Dengan kata lain, tuntutan mendialogkan al-Qur'an dengan realitas menjadi spirit tersendiri bagi dinamika itu. ${ }^{19}$ Jika tafsir dengan maqâshid al-Qur'ân memiliki arah yang sama, bukan sesuatu yang mustahil bahwa dinamika maqâshid itu perlu kita afirmasi. Dalam konteks maqâshid al-Qur'ân menurut Hasan Khân, tidak keliru ketika beranggapan bahwa pandangan maqâsshid-nya berjalan beriringan dengan metode penafsiran yang ia pakai, dan senantiasa erat berkaitan dengan konstruksi realitas yang mengelilinginya.

Sebelum mengulas maqâshid al-Qur'ân menurut Hasan Khân, yang dapat kita tempuh dengan mengulas penafsirannya, menarik sekali untuk diperhatikan perkataan Hasan Khân dalam mukadimah tafsir Fath al-Bayân fî Maqâshid al-Qur'ân berikut:

"Dan tujuan daripadanya (penafsiran al-Qur'an) ialah mengetahui konstruksi makna dan hukum-hukum syariat praktis yang berfaedah untuk menghasilkan kemampuan mengistinbat hukum syariat secara otoritatif (al-shihhah). Objeknya ialah kalam Allah Swt. yang merupakan sumber segala hikmah serta penengah setiap aspek. Tujuannya ialah sampai terhadap pemahaman makna-makna al-Qur'an lalu mengambil hikmahnya agar memperoleh keuntungan duniawi-ukhrawi. Dan (tafsir) merupakan ilmu paling mulia berdasarkan keluhuran objek dan tujuannya. Ia adalah semulia dan seagung-agungnya pengetahuan, seperti dikatakan oleh para pemuka agama (shadr al-dîn)."20

Ungkapan pendahuluan tersebut secara eksplisit menggambarkan pandangan Hasan Khân tentang maqâshid al-Qur'ân. Seperti yang telah penulis katakan sebelumnya hal-ihwal tafsir dan maqâshid al-Qur'ân, Hasan Khân juga memiliki pandangan bahwa tujuan akhir penafsiran ialah memahami esensi al-Qur'an (fahm ma'ânî al-Qur'ân). Bahkan, tujuan tersebut berkaitan erat dengan tuntutan istinbat hukum secara sahih berdasarkan esensi tersebut. Jika demikian adanya, maka maqâshid al-Qur'ân yang ditawarkan Hasan Khân bukan sesuatu yang statis, melainkan dinamis, sebab istinbat hukum senantiasa melibatkan realitas sosial-budaya serta waktu pengistinbatan itu dilakukan. Konsekuensi logis dari tesis semacam itu ialah kita harus berani mengatakan bahwa bisa saja maqâshid Hasan Khân itu tidak sama dengan maqâshid kita, lantaran abad ke-21 masa kita hidup secara realitas berbeda jauh dari abad ke-19, masa Hasan Khân. Belum lagi konstruksi sosial-kebudayaan di daerah secara spesifik, yang kadang memiliki perbedaan signifikan kendati berada di abad yang sama.

Agar lebih jelas, penulis menguraikan penafsiran Hasan Khân tentang surah al-Nisâ' [4]: 1-5 sebagai berikut:

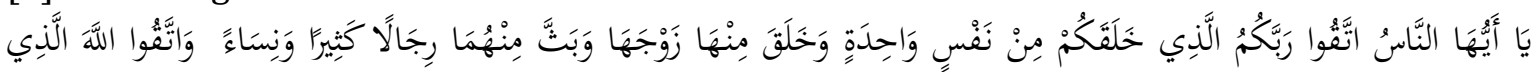

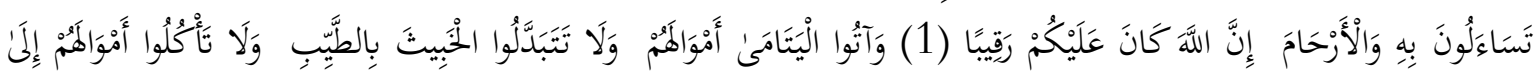

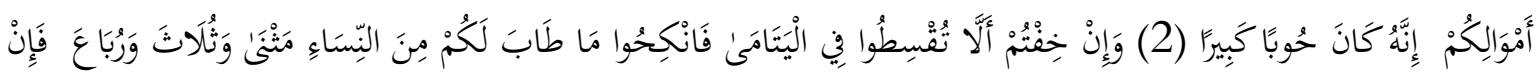

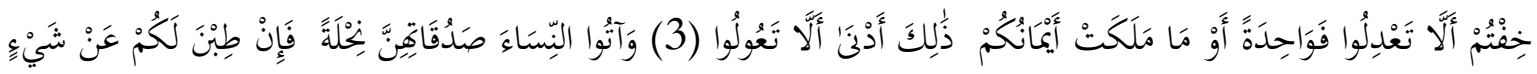

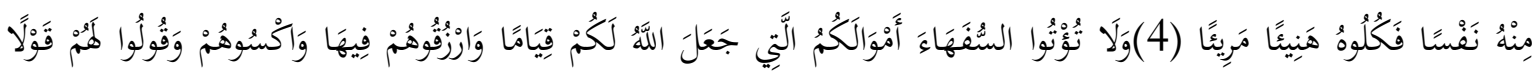

\footnotetext{
18 U Fikriyati dan Ahmad Fawaid, "Pop-Tafsir on Indonesian YouTube Channel: Emergence, Discourse, and Contestations," Proceeding AICIS 2019, Oktober, hlm. 2.

${ }^{19}$ Mustaqim, Epistemologi Tafsir Kontemporer, hlm. 1.

${ }^{20}$ Hasan Khân, Fath al-Bayân fî Maqâshid al-Qur'ân, juz 3, hlm. 11-2.
} 
Hasan Khân menafsirkan ayat tersebut secara kata perkata, seperti umumnya tafsir-

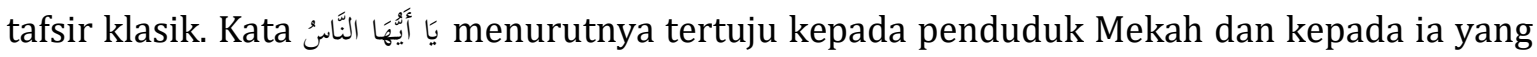

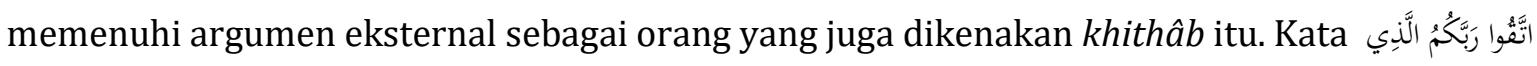
خَلَكَكُمْ merepresentasikan seruan agar takut terhadap pembalasan, larangan terhadap kufur nikmat. Sebab Allah-lah yang memiliki kekuasan ekstensif untuk menyiksa, misalnya. Kalimat ditafsirkan sebagai rangkaian penciptaan manusia; Adam, Hawa, lalu keturunannya. Hasan Khân mengutip pendapat Ibn Mas'ûd dan Ibn 'Abbâs perihal penciptaan Hawa, apakah ia diciptakan sebelum berada di surga atau justru setelah berada di dalamnya. Bagian tersebut menyiratkan unsur al-ma'tsûr dari tafsir Hasan Khân. ${ }^{21}$

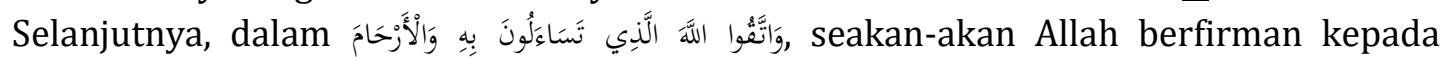
manusia: takutlah kalian untuk memutus kasih-sayang. Sebab memutus silatutahmi termasuk dosa besar. Silaturahmi merupakan pintu segala kebaikan yang dapat menambah usia dan keberkahan rezeki, sedangkan memutusnya menjadi musabab lahirnya segala kemungkinan buruk. Maka dari itu sambunglah silaturahmi dengan takwa kepada Allah-Tuhan tempat kalian semua meminta sesuatu. Hasan Khân kemudian mengutip pendapat al-Qurthubî, bahwa semua agama sepakat hal-ihwal wajibnya silaturahmi dan haram memutusnya. Atas

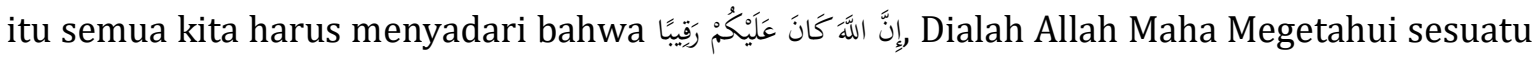
yang samar juga yang tampak. Dia yang Maha Dekat dan Mengawasi kita. ${ }^{22}$

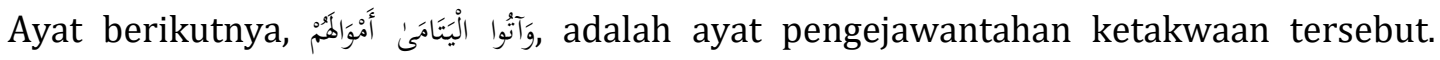
Dimulai dengan sesuatu yang berkaitan dengan para yatim, guna memperlihatkan pertolongan serta menemani mereka dengan kasih sayang. Objek khithâb tersebut adalah para wakil (al-waliyy) dan para pelaksana wasiat (al-awshiyố). Yatim yang dimaksud ialah mereka yang hidup tanpa bapak, dan diperinci syariat, sebagai anak tanpa bapak yang belum balig. Batasan ayat tersebut disebutkan kemudian, yakni pada ayat 6, bahwa harta diberikan kepada sang yatim bilamana ia sudah pintar (al-rusyd), dalam arti mampu menjaga dan

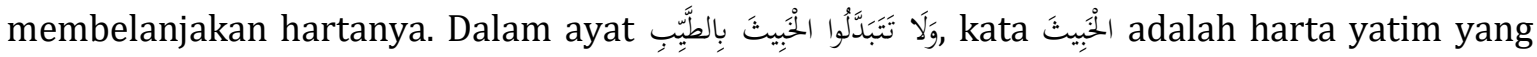
halal, sedangkan kata بإلطَِّّ adalah harta kita yang haram. Hasan Khân memahami ayat tersebut sebagai sebuah larangan memakai harta baik anak yatim karena itu tetap haram, sedangkan harta kita halal meskipun harta itu sendiri buruk adanya. Tradisi demikian merupakan adat Jahiliah, dan al-Qur'an menentangnya. Kendati begitu, Hasan Khân juga mengutip pendapat mufasir lain; ayat tersebut mewanti-wanti kita agar tidak terburu-buru makan harta yang buruk, namun menunggu rezeki halal dari Allah Swt. Hasan Khân berpendapat, penafsiran paling kuat, ayat tersebut memerintahkan kita agar tidak memakan harta yatim, sebab itu buruk dan haram hukumnya, sekaligus meminta kita mencari rezeki sendiri yang halal. ${ }^{23}$

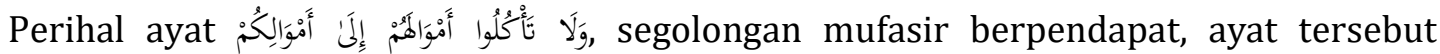
merupakan larangan mencampur harta kita dengan harta yatim. Mengumpulkan harta yatim adalah suatu keharaman, tetapi spesifikasi larangannya tetaplah sisi 'mencampurnya'.

${ }^{21}$ Ibid., hlm. 9-10.

22 Ibid., hlm. 11.

${ }^{23}$ Ibid., hlm. 12. 
Spesifikasi tersebut bertujuan untuk mengumpat (al-tashnî) para pelakunya. Namun bukan berarti mafhûm mukhâlafah-nya mengizinkan kita memakan harta yatim an sich, semuanya tetaplah haram. Semua tindakan tersebut, yakni makan dan mencampur harta yatim, tergolong perbuatan dosa yang amat besar. Hasan Khân mengutip Ibn Zayd yang berkata: "Para penduduk Jahiliah tidak memberikan warisan kepada perempuan dan anak-anak. Para tetua mengambilnya. Maka pembagian warisannya baik, tetapi mengambilnya adalah suatu

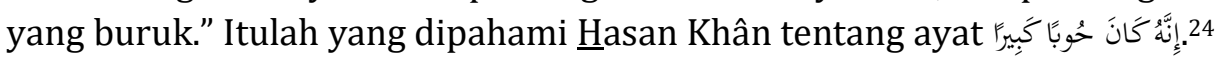

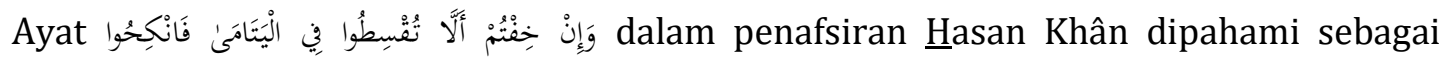
langkah terciptanya ikatan bersyarat. Ayat ini turun membicarakan seseorang yang berperan sebagai wali dari yatim perempuan, mencukupi segala kebutuhannya. Ketika yatim tersebut dewasa, si wali ingin menikahinya namun tidak memberikan mahar, tidak pula bersikap adil dan tidak menunaikan hal-ihwal yang menjadi hak seorang istri pada umumnya. Maka Allah Swt. melarang mereka, para wali, untuk menikahi sang yatim kecuali jika berbuat adil dan memberikan mahar sebagaimana seharusnya. Allah Swt. kemudian juga memerintahkan kepada para wali itu untuk menikahi wanita semampu mereka melakukannya. Hasan Khân mengutip mufasir salaf, Abû 'Ubayd yang mengatakan bahwa خِفٌُْ bermakna "yakin" dan juga bisa bermakna "menyangka". Pendapat tersebut dilanjutkan oleh Ibn "Athiyyah, bahwa konteks lafaz tersebut dalam hal prasangka, bukan keyakinan akan tidak dapat berbuat adil. Demikianlah, ayat tersebut menasakh perilaku Jahiliah pra-Islam yang membolehkan lelaki menikah sebanyak mereka mau. ${ }^{25}$ Pembatasan jumlah juga ditetapkan al-Qur'an, seperti yang akan diuraikan kemudian.

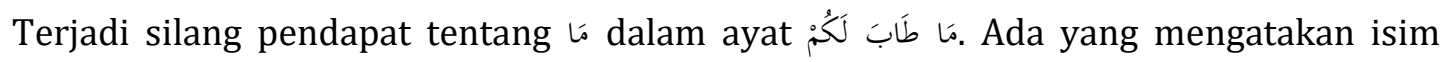
maushûl, na'at, bahkan 'ó mashdariyyah. Pendapat terakhir ini dianggap terlalu jauh. Tetapi, menurut Hasan Khân, para cendekiawan sepakat bahwa kata tersebut mengindikasikan kebolehan menikah lebih dari satu wanita, jika merasa mampu bersikap adil. Kata منَ النِنسِاٍ bisa disebut bayâniyah dan juga tabî̂dhiyah. Sebab, dengan melihat konteks diksionalnya, itu bukan untuk para wanita yatim melainkan wanita secara umum (al-ajnabiyyât). Penafsiran Hasan Khân ini jelas berbeda dengan penafsiran kontemporer, yang memahami ayat tersebut sebagai bagian integral dari yatim itu sendiri. Konteks ayatnya membahas tentang yatim, dan wanita-wanita dalam ayat tersebut dikembalikan kepada konteks saat turunnya ayat, yaitu para istri dari wali sang yatim. ${ }^{26}$ Tentu saja perbedaan diametral ini memiliki implikasi terhadap pemahaman konteks universal yang dibahas ayat itu sendiri. Penafsiran kontemporer tidak memahaminya sebagai ayat poligami, melainkan tentang keadilan (justice). ${ }^{27}$

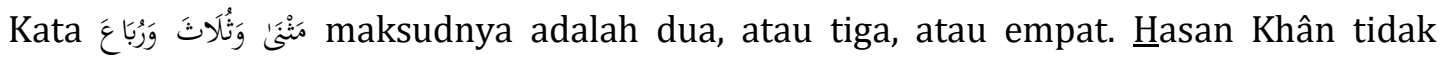
memahami jumlah tersebut secara kalkulatif menjadi sembilan. Ia menganggap mufasir yang

24 Ibid., hlm. 13.

25 Ibid., hlm. 14.

${ }^{26}$ Lihat, misalnya, Muhammad al-Râzî Fakhr al-Dîn, Tafsîr al-Fakhr al-Râzî al-Mushtahir bi al-Tafsîr alKabîr wa Mafâtîh al-Ghayb, juz 9, (Beirut: Dâr al-Fikr, 1981), hlm. 178.

27 Adil kepada yatim, adil kepada istri, dan sebagainya. Lebih lengkap lihat Amina Wadud,Qur'an and Women; Rereading the Sacred Text from a Woman's Perspective,(New York: Oxford University Press, 1999), hlm. 83. 
berpendapat demikian sebagai orang yang buta bahasa Arab. Melalui batasan jumlah tersebut, menurutnya, maka menikahi perempuan lebih dari empat hukumnya haram. Seseorang diberikan opsi perihal jumlah itu semampu mereka, baik dua, tiga, maupun empat.

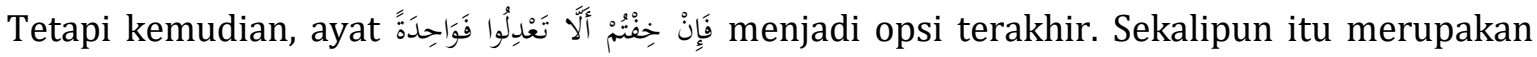
khithâb untuk semuanya, tetapi ia mengandung pesan interpersonal. Keadilan yang menjadi syarat adalah dalam hal pembagian waktu, nafkah, dan sejenisnya. Jika itu tidak mampu maka cukup dengan menikahi satu wanita. Dan tidak boleh lebih dari satu, bagi orang yang mengkhawatirkan terjadinya ketidakadilan. Atau boleh lebih dari satu, asal yang kedua dan seterusnya adalah selir (budak). Kebolehan itu karena mereka tidak memiliki hak yang sama seperti seorang istri, tidak ada tuntunan untuk bertindak adil memperlakukan mereka seperti memperlakukan seorang istri. Itu yang dipahami Hasan Khân dalam ayat أَوْ مَا مَكَكَتْ 28

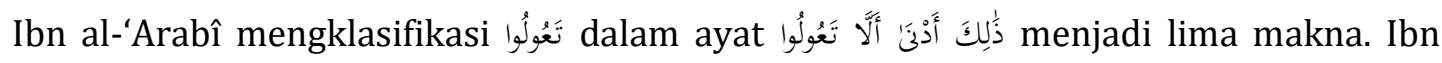
'Athiyyah, al-Râzî, Thalhah, Qatâdah, al-Dhahhak, Ibn Mundzir, Ibn Hibbân, bahkan Ibn 'Abbâs memiliki pandangan tersendiri tentang makna تَعُوُولُو Hasan Khân tidak memberikan komentar pribadi tentang makna kata tersebut. Ia hanya memaparkan perbedaan pendapat ulama dalam pemaknaannya. ${ }^{29}$ Pada ayat ke-4, وَآتُوا النِّنَاءَ merupakan khithâb untuk para suami perihal

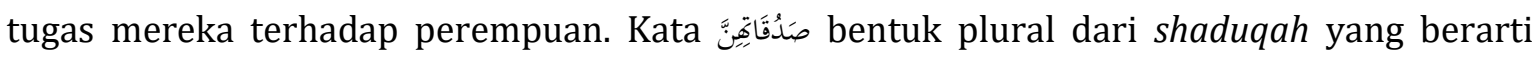

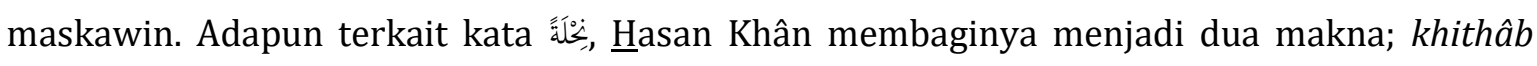
pada para suami dan pada para wali yatim. Ayat tersebut berseru kepada para suami, "berikanlah kepada wanita-wanita yang kamu nikahi mahar mereka, dalam bentuk tunai maupun hutang. Itu wajib bagimu dan baik untuk dirimu." Dan seakan juga berkata kepada para wali, "berikanlah kepada wanita-wanita dari kerabatmu mahar mereka yang kau hutang." Pernyataan terakhir ini sebagai penegasan, karena di tradisi Jahiliah, mengambil mahar kerabatnya merupakan hal lumrah dan tidak memberikan apapun pada mereka. Hasan Khân menceritakan itu dari Abû Shâlih dan al-Kalbîy. ${ }^{30}$

Pada ayat ke-5, dan ini ayat terakhir yang penulis jadikaan sampel dalam mengkaji penafsiran Hasan Khân, Allah Swt. kembali memberi penegasan terkait harta sang yatim.

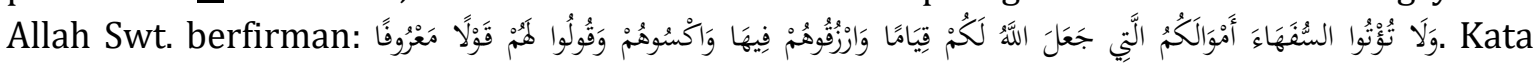
السَُفَكَءَ menurut Hasan Khân ialah orang-orang yang suka mubazir, baik lelaki, perempuan, maupun anak (yatim). Ini merupakan kilas balik terhadap perintah memberikan harta anak yatim di ayat ke-2. Artinya, Allah Swt. melarang pengembalian harta tersebut ke tangan mereka jikalau mereka tergolong 'safíh'-tidak mampu membelanjakan hartanya secara

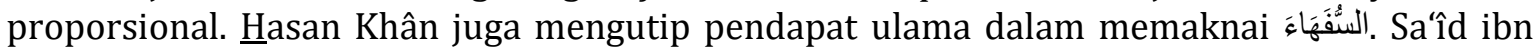
Jubair mengatakan, mereka adalah para yatim yang tidak boleh diberikan hartanya. Menurut Mâlik, mereka adalah anak-anak kecil yang jika diberikan harta, akan dibelanjakannya hingga tak tersisa sedikit pun. Sedangkan Mujâhid mengartikan mereka sebagai para wanita. ${ }^{31}$

\footnotetext{
${ }^{28}$ Hasan Khân, Fath al-Bayân fî Maqâshid al-Qur'ân, juz 3, hlm. 16-8.

${ }^{29}$ Ibid., hlm. 19-20.

${ }^{30}$ Ibid., hlm. 21.

31 Ibid., hlm. 23.
} 


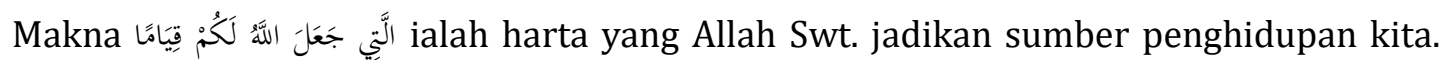

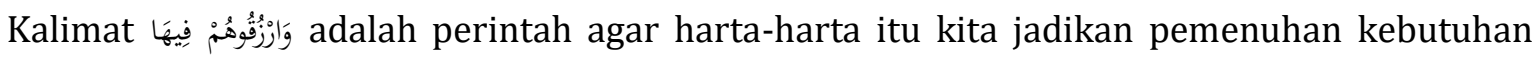
pangan, yakni menafkahi mereka dengan harta yang tidak mampu mereka belanjakan sendiri. Selain menafkahi, Allah Swt. juga memerintahkan agar وَاكْسُوهُمْ yakni memenuhi kebutuhan sandang mereka. Ayat tersebut menjadi argumentasi kebolehan mencegah mereka menggunakan sendiri hartanya. Tetapi Hasan Khân kemudian mengutip Abû Hanîfah yang berpendapat bahwa jika mereka sudah balig dan akalnya sempurna, maka larangan membelanjakan tersebut jadi gugur. Allah Swt. menutup serangkaian bimbingan di ayat ke-5

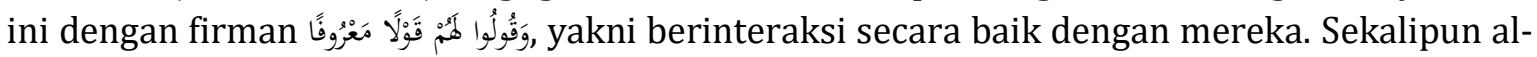
Qur'an menyebut mereka sebagai sufahâ', namun sang wali tetap wajib berbicara secara baikbaik, menyambung silaturahmi erat dengan mereka. Ayat ini secara eksplisit menuntun kita menuju pekerti luhur ( husn al-khuluq) terhadap keluarga, anak, atau para yatim. ${ }^{32}$ Kendati demikian tetap mesti diingat, bahwa kita tidak diperbolehkan mencampur harta kita dengan para yatim itu. Kita hanya dituntut mengembalikannya, dan jika mereka tidak memiliki kecakapan menggunakannya, tugas kita adalah membelanjakan harta tersebut untuk kebutuhan mereka sendiri.

Sekarang jika kita tilik dari tafsir salaf, maka akan ditemukan banyak kesamaan. Tafsir al-Thabarî, yang merupakan tafsir normatif ( $b i$ al-ma'tsûr) generasi awal, memiliki kesamaan

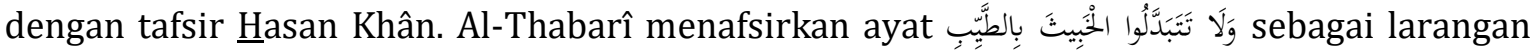
mencampur (al-khalth) harta halal dengan haram, atau perintah agar kita tidak terburuburu-meminta kita bersabar menunggu harta halal dari Allah Swt., tidak dengan menggantinya dengan harta yatim. ${ }^{33}$ Selain tafsir al-Thabarî, kita juga bisa menilik tafsir Hasan Khân dengan al-Tafsîr al-Kabîr-nya Fakhr al-Dîn al-Râzî yang lebih rasional (bi al-ra'y).

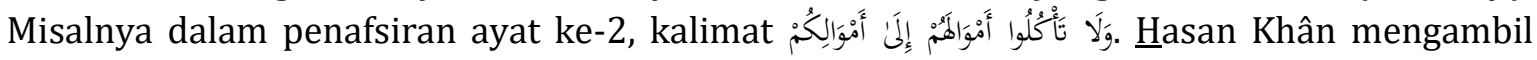
pendapat terkuat (râjih) al-Râzî yang mengatakan bahwa maksud ayat tersebut ialah larangan mencampur harta kita dengan harta yatim, sehingga sekat antara kedua harta tersebut tidak jelas. Menurut hemat penulis, dalam konteks tafsir salaf, kita akan menemukan pelbagai kesamaan bahkan identik. Itu adalah sesuatu yang lumrah. Hal demikian mirip yang dikatakan Nur Kholis bahwa penafsiran klasik tidak lebih sekadar kajian repetitif (qirâah mutakarrirah) ketimbang kajian produktif (qirâah muntijah). Tafsir dianggap sebagai proses final dalam memaknai kalam Tuhan, tidak sebagai proses kontinu sebab relativitas produk penafsiran itu sendiri. ${ }^{34}$

Dalam surah al-Nisâ' [4]: 1-5 di atas, Hasan Khân berusaha mengintinbat hukum tentang yatim dan sesuatu yang berhubungan dengannya. Tetapi upaya Hasan Khân berjalan secara kronologis, bukan tematik. Sehingga pemahaman itu pun bukan kajian detail-spesifik, meskipun kandungannya dapat tertangkap oleh mufasir. Mula-mula Hasan Khân menerangkan tentang penciptaan manusia seperti pada ayat ke-1. Pembahasan tentang

\footnotetext{
32 Ibid., hlm. 24-5.

33 Muhammad ibn Jarîr al-Thabarî, Jâmi' al-Bayân 'an Ta'wîl Âyi al-Qur'ân, cet. ke-2, juz 7, (Kairo: Maktabah Ibn Taimiyah, t.t.), hlm. 525-26.

34 M. Nur Kholis Setiawan, "Al-Qur'an dalam Kesarjanaan Klasik dan Kontemporer; Keniscayaan Geisteswissenschaften,” Jurnal Studi al-Qur'an, vol. 1, no. 1, (2006), hlm. 80.
} 
penciptaan Hawa, pasangan Adam, merupakan titik tolak konsep keadilan, yaitu diawali dengan pernyataan ekualitas manusia, baik lelaki maupun perempuan yang berasal dari satu jiwa (nafs). Untuk sebuah tawaran konsep keadilan, itu adalah pengenalan menarik. Hasan Khân menangkap pesan itu, namun tetap dengan merujuk literatur salaf, sebab tafsirnyasebagaimana diulas di awal-lebih mendominasi riwayat daripada rasionalitas mufasir. Setelah berbicara hal-ihwal ekualitas, yang tertangkap berikutnya oleh Hasan Khân ialah sistem simbiosis mutualisme di antara dua jenis ciptaan tersebut. Oleh sebab itu, Allah Swt. memerintah manusia untuk selalu menjaga harmoni antarsesama, dengan landasan ketakwaan kepada-Nya. Hasan Khân menangkap pesan itu melalui konstruksi penafsirannya di ayat pertama.

Ayat kedua oleh Hasan Khân dipahami sebagai inti pembicaraan, yakni keadilan terhadap yatim. Dengan mengatakan bahwa khithâb yang terkandung dalam kata وَآَتُو (ang merujuk pada kata النَّاس di ayat pertama adalah untuk para wakil (al-walîy) dan para pelaksana wasiat (al-awshiyấ), Hasan Khân menitikberatkan keadilan tersebut untuk keduanya, lantaran pada masa itu eksploitasi terhadap wanita dan para yatim tergolong suatu yang legal. Al-Qur'an mewanti-wanti untuk berbuat adil, tidak semena-mena terutama pada harta mereka. Larangan keras dengan nada persuasif ditempuh al-Qur'an dengan kata

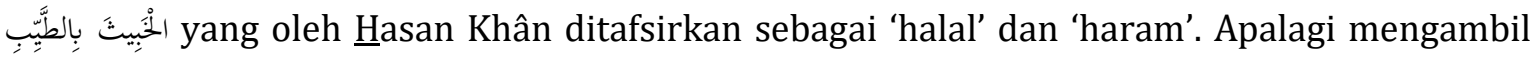
seutuhnya, bahkan mencampurnya saja dikategorikan sebagai dosa yang besar.

Konsep tentang keadilan dipahami Hasan Khân dalam ayat ketiga, yakni ketika alQur'an memberi solusi atas tendensi kealpaan keadilan itu dalam kehidupan poligami. Tetapi sekali lagi, Hasan Khân — sesuai spirit ayat-menitikberatkan topik bahasan terhadap keadilan an sich, bukan poligaminya. Itu dapat dilihat ketika anjuran satu istri tetap menjadi prioritas, apabila sang wali atau suami dikhawatirkan tidak mampu menciptakan keadilan dalam kehidupan pernikahannya. Bahwa Hasan Khân memahami esensi kelima ayat tersebut adalah tentang keadilan juga dapat kita temukan dalam ayat kelima, ketika ia mengatakan bahwa kewajiban suami atau wali tidak lain senantiasa hidup rukun-berkeadilan bersama istri dan para yatim. Kita telah melihat bahwa kerukunan tersebut merupakan sesuatu yang mustahil tanpa adanya keadilan.

Dengan demikian, melalui penafsiran ayat satu sampai lima, Hasan Khân hendak menarasikan keadilan demi terwujudnya kerukunan silaturahmi, utamanya antarkeluarga. Kasus para wanita (al-nisâ) dan para yatim (al-yatâmâ) dipahami sekadar sebagai pintu masuk menuju ajaran keadilan tersebut. Itu tidak lebih hanya sebagai sampel kasus, lantaran keadilan paling sulit adalah perihal 'harta' dan 'kasta'. Harta membuat seseorang lalai berlaku adil, hal yang sama ketika seseorang dihadapkan dengan ketimpangan kasta. Para wali merupakan rupa metaforis dari 'kasta tinggi', dan yatim metafora dari 'kasta rendah'. Eksploitasi finansial memanglah rentan, di samping sebagai respons masyarakat, karena ketika ayat tersebut turun perlakuan demikian lumrah adanya. Atas semua realitas itu, Hasan Khân menegaskan bahwa keadilan harus tetap tegak, terlepas dari ketimpangan apapun dari semua pihak. Baik beda harta maupun kasta, kita mesti menjaga silaturahmi-kerukunan, sesuatu yang oleh $\underline{H}$ asan Khân disebut sebagai manifestasi pekerti luhur ( $\underline{h} u s n$ al-khuluq) yang dituntunkan al-Qur'an. ${ }^{35}$

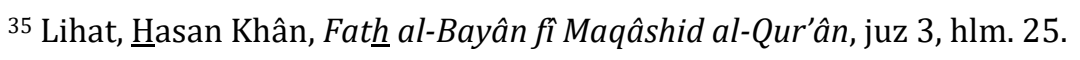


Itulah substansi kelima ayat tersebut menurut Hasan Khân, kendati ia menguraikannya secara analitis (tahlîîî), bukan secara tematik (mawdhûî̉), sehingga maqâshid tersebut pun dinarasikan secara implisit, tidak secara eksplisit. Maqâshid surah al-Nisâ' [4]: 1-5 menurut Hasan Khân ialah tentang keadilan untuk para yatim serta harmoni rumah tangga. Di samping itu, kelima ayat tersebut hakikatnya mengajarkan manusia tentang husn al-khuluq. Jika memakai kacamata analisis 'Abd al-Karîm Hâmidî, kelima ayat tersebut mengandung dua maqâshid, yaitu kemaslahatan kolektif (al-shalâh al-ijtimâ̂î) dan kemaslahatan universal (alshalâh al-'âlamîi). ${ }^{36}$

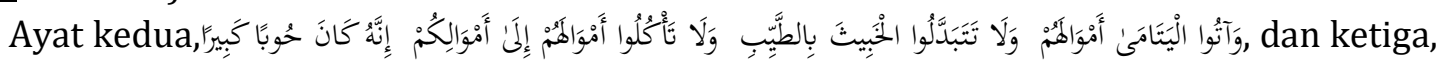

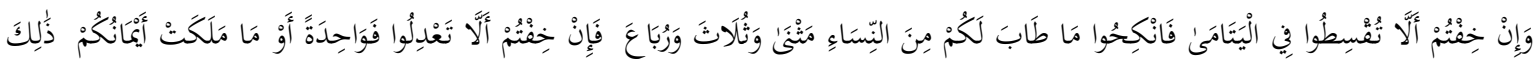

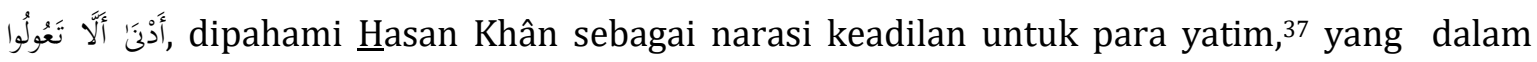
klasifikasi Hâmidî ini masuk kategori upaya mencapai kemaslahatan universal (al-shalâh al-

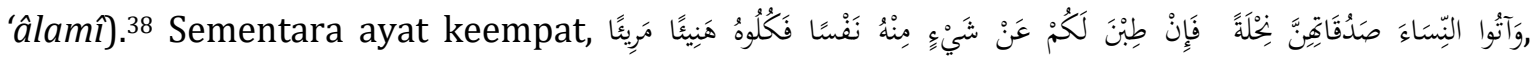

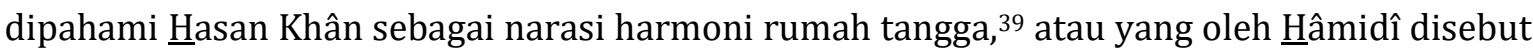
upaya kemaslahatan keluarga (al-ishlâh al-'ấilî), dan ini tergolong upaya mencapai kemaslahatan kolektif (al-shalâh al-ijtimâ'î). ${ }^{40}$ Termasuk juga dalam al-shalâh al-ijtimấî ini ialah ayat kelima, karena husn al-khuluq yang dipahami Hasan Khân adalah demi kemaslahatan kolektif; kita dengan para yatim.

Hakikat maqâshid al-Qur'ân menurut Hasan Khân sepadan dengan maqâshid dalam pandangan mufasir Abad Pertengahan. Al-Juwaynî mengistilahkannya dengan keniscayaan umum (al-hhâjât al-'âmmah), dalam artian bahwa maqâshid bertujuan sebagai 'penjagaan', baik akidah, jiwa, akal, aurat, serta harta. Ayat kelima surah al-Nisâ' yang oleh Hasan Khân ditarik maqâshid-nya dengan mengatakan bahwa ayat tersebut merupakan tuntunan alQur'an tentang pekerti agung ( $\underline{h} u s n$ al-khuluq), seperti diuraikan sebelumnya. Ini jelas mirip dengan 'Izz al-Dîn ibn 'Abd al-Salâm yang mempersepsikan maqâshid sebagai filosofi hukumhukum (al-hikmah min warâ' al-ạhkâm). ${ }^{41}$ Tetapi keselarasan tersebut berada dalam konstruksi ontologis an sich, karena lanskap maqâshid Hasan Khân berada dalam ranah yang lebih luas, tidak melulu hanya dalam konteks maqâshid ayat-ayat hukum atau yang kita kenal

${ }^{36}$ Selengkapnya lihat, 'Abd al-Karîm Hâmidî, Maqâshid al-Qur'ân min Tasyrî' al-A $\underline{h} k a ̂ m$, cet. ke-1, (Beirut: Dâr Ibn Hazm, 2008), hlm. 255, 269, dan 541.

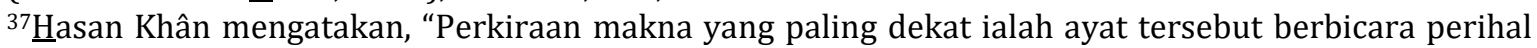
keadilan untuk para yatim." Lihat, ㅂasan Khân, Fath al-Bayân fị Maqâshid al-Qur'ân, juz 3, hlm. 15.

${ }^{38}$ Keadilan adalah satu dari lima kemaslahatan universal dalam ulasan Hâmidî. Silakan lihat, Hâmidî, Maqâshid al-Qur'ân min Tasyrî̀' al-Ahkâm, hlm. 511 dan 541.

${ }^{39}$ Hasan Khân mengatakan, "Makna ayat tersebut ialah hak para suami terhadap wanita yang dinikahinya, juga untuk para wali dari mempelai wanita untuk juga membayar mahar yang dihutangnya. Ayat tersebut menunjukkan kewajiban memberi mahar kepada seorang istri." Lihat, Hasan Khân, Fath al-Bayân fí Maqâshid al-Qur'ân, juz 3, hlm. 21.

${ }^{40}$ Ada tiga aspek kemaslahatan kolektif, yaitu islah keluarga (al-ishlâh $\underline{h}$ al- 'â'ilî), islah harta (al-ishlâh al-mâlî), dan islah 'iqâbî. Dari ketiga aspek tersebut, islah keluarga di antaranya ialah argumen menjaga hubungan suami-istri (al-nushûsh al-dâllah 'ala hifzh al-'alâqah al-zawjiyyah). Lihat, Hâmidî, Maqâshid al-Qur'ân min Tasyrî' al-Ahkâm, hlm. 254 dan 275.

${ }^{41}$ Jasser Auda, Maqâsshid al-Syarî́ah Dalîl li al-Mubtadiîn, cet. ke-1, (Washington: Ma'had al-'Âlamî li alFikr al-Islâmî, 2011), hlm. 46-9. 


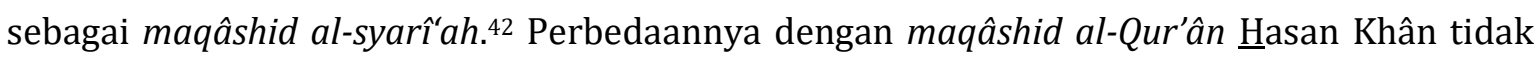
kentara, sebab Hasan Khân menelisiknya secara analitis. Ia tampak seperti mengulas maqâshid al-syarî'ah, padahal bukan. Yang menjadi titik tekan Hasan Khân adalah maqâshid al-Qur'ân, makna-makna esensial dari al-Qur'an, meskipun tampak atomistis. Atau, secara ontologis, maqâshid al-Qur'ân menurut Hasan Khân terklasifikasi ke dalam tiga kategori, yaitu tafsir sebagai proses final, maqâshid sebagai makna autentik, dan riwayat sebagai kunci maqâshid.

\section{Epistemologi Tafsir Fath al-Bayân fî Maqâshid al-Qur'ân}

Untuk mencapai aspek ontologis makna al-Qur'an, Hasan Khân memerlukan seperangkat metodologi yang menjadi titik tolak dirinya mencapai maqâshid itu. Sebuah hakikat tidak akan pernah terungkap kecuali setiap langkah terhadapnya ditempuh secara tepat dan sistematis. Tolok ukur kebenaran juga ditentukan oleh langkah metodis tersebut. Penafsiran Hasan Khân seluruhnya, termasuk di dalamnya lima ayat surah al-Nisâ' di atas, senantiasa berada di jalur metodologis yang ditetapkan Hasan Khân sendiri. Hakikat konseptual tafsir sebagai proses final, maqâshid sebagai makna autentik, serta riwayat sebagai kunci mencapai maqâshid diperoleh Hasan Khân melalui metodologi itu. Pertanyaan dasar epitemologis itu oleh Hasan Khân dijadikan pangkal munculnya dua aliran besar. Pertama, aliran yang berpandangan bahwa manusia bisa mengetahui, atau disebut i'tiqâdiyyûn, dan kedua, aliran yang meragukan kemungkinan manusia mengetahui, disebut aliran keraguan (syakk). Epistemologi i'tiqâdiyyûn meyakini adanya kebenaran melalui indra dan akal, sehingga lahirlah epistemologi rasional dan epistemologi empiris. Sementara epitemologi keraguan (syakk) terklasifikasi menjadi empat: epistemologi keraguan mutlak, epistemologi keraguan muqallidah, epistemologi keraguan îmânî, dan epistemologi keraguan metodologis. ${ }^{43}$

Dalam menafsirkan kelima ayat surah al-Nisâ' di atas misalnya, Hasan Khân begitu berhati-hati ketika hendak mengutip pendapat mufasir salaf. Kisah isrấîliyyât benar-benar disaring, dan riwayat yang mengalami ketidakjelasan sanad tidak dikutipnya. Semua riwayat disertai sumber yang valid, dan yang paling kuat dijadikan acuan utama makna ayat yang sedang ditafsirkan. Hasan Khân kemudian meyakini bahwa demikianlah maqâshid-nya, substansi makna yang Allah Swt. maksudkan. Pengutipan riwayat Ibn 'Abbâs, Qatâdah, al-

42 Maqâshid al-syarî‘ah memuat esensi hukum yang dituju syâri', sedangkan maqâshid al-Qur'ân mencakup sudut pandang universal akan ketentuan al-Qur'an. Karenanya dipahami bahwa memahami maqâshid al-Qur'ân tidak boleh tidak terlebih dahulu menguraikan maqâshid al-syarî'ah, kecuali selain ayat hukum. Lihat, Wafâ' bint Dakhîl Allâh ibn 'Âbid al-Khitâbî, "Maqâshid al-Qur'ân al- 'Âmmah," dalam Muhammad Abû al-Layts al-Khayr Âbâdî (ed.), Al-Wahyy wa al-'Ulûm fî al-Qarn al-Wâhid wa al'Isyrîna, cet. ke-1, (Malaysia: IIUM Press, 2011), hlm. 211.

43 Epistemologi keraguan mutlak sama sekali menegasikan kemampuan akal dan indra untuk mencapai pengetahuan dan juga kebenaran. Epistemologi keraguan muqallidah meyakini adanya kebenaran tetapi tidak dicapai melalui akan maupun indra, melainkan dari sosok manusia suci (ma'shûm) seperti 'Alî ibn AbîThâlib. Epistemologi ini senafas dengan epistemologi keraguan îmânî yang mempersepsikan wahyu semata sebagai otoritas mencapai kebenaran.Sedangkan epistemologi keraguan metodologis meyakini bahwa manusia mungkin dapat mencapai kebenaran, namun ditempuhnya secara kritis.Ia mencoba sintesis indra dan akal. Dalam epistemologi ini, kebenaran diperoleh secara objketif dengan paradigma kritis. Selengkapnya lihat Aksin Wijaya, Nalar Kritis Epistemologi Islam, cet. ke-2, (Yogyakarta: Teras, 2013), hlm. 28-34. 
Râzî, dan mufasir lainnya merefleksikan epistemologi Hasan Khân dalam mencari maqâshid al-Qur'ân. Meminjam klasifikasi Aksin Wijaya, Hasan Khân termasuk aliran epistemologi keraguan muqallidah, yakni berlandaskan keyakinan bahwa yang memiliki otoritas mencapai kebenaran adalah 'orang-orang tertentu'. Tetapi bukan karena kemaksumannya, melainkan kredibilitas riwayat-bersambung hingga Nabi saw. dan bebas dari manipulasi isrâ'îliyyât. Adapun bila menggunakan nalar epistemologis 'Âbid al-Jâbirî, tafsir Hasan Khân menggunakan epistemologi bayânî. Tafsir tersebut tidak berusaha mencapai kebenaran dengan bertolak pada intuisi mapun nalar kritis, melainkan aspek kebahasaannya. Yang terakhir ini paling dekat dengan diri Hasan Khân.

Hasan Khân menggunakan epistemologi bayânî ${ }^{44}$ dalam menafsirkan ayat. Ia menitikberatkan pada aspek gramatikal ayat, sebab menafsirkan secara kata perkata, menelisik secara teologis, atau pun mengutip pendapat mufasir sebelumnya sebagai referensi

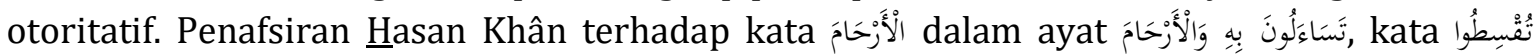

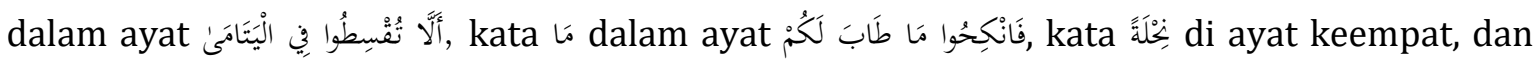

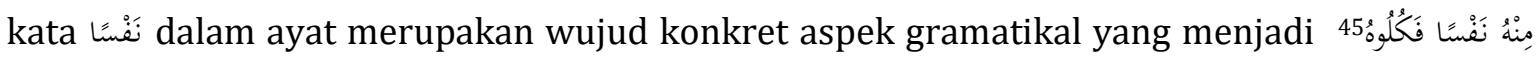
perhatian Hasan Khân. Selain itu, aspek yurisprudensi juga menjadi bagian dari upaya Hasan Khân dalam mencapai maqâshid. Seperti ketika menafsirkan perihal keharaman beristri lebih dari empat, pengutipan kepada al-Syâfi'î, serta Abû Hanîfah pada ayat kelima. ${ }^{46}$ Epistemologi bayânî Hasan Khân juga ditilik melalui penafsirannya tentang hubungan horizontal antarsesama ( Asy'arî. 47

Epistemologi bayânî Hasan Khân ini merupakan sesuatu yang lumrah, karena secara periodik ketika itu dua epistemologi lainnya, 'irfânî dan burhânî belum tersebar. Meskipun ia semasa dengan pelopor pembaharuan Islam di India, seperti Sayyid Ahmad Khân (w. 1898) dan Muhammad Iqbâl (w. 1938), namun Hasan Khân mengabdikan karir intelektualnya untuk berpegang teguh kepada tradisi ketimbang modernitas. Dengan kata lain, daripada mencari kompatibilitas Islam dan modernitas Eropa, di bawah cengkeraman kolonialisme Inggris ketika itu, Hasan Khân lebih memilih mempertahankan diri untuk menjadi tradisionalis. Sebagai konsekuensinya, paradigma epistemologis yang ia pakai juga tidak bersentuhan dengan rasionalitas Eropa, melainkan tetap konsisten dengan tradisi yang sudah ada sejak lama di India, yaitu tradisi salaf. Kendatipun demikian, terdapat benang merah yang meski kita pahami dari lahirnya dua epistemologi tersebut, yaitu sama-sama merupakan respons terhadap kolonialisme. Hanya saja responsnya berada pada ranah yang tidak sama. Epistemologi bayânî merespons secara konfrontatif, yang dalam konteks Hasan Khân dapat kita lihat ketika gelar kehormatannya dicabut oleh Inggris, meski juga kelak diberikan

\footnotetext{
${ }^{44}$ Nalar bayânî Hasan Khân tidak hanya terdapat dalam tafsirnya, bahkan dapat dibuktikan dengan intensitasnya terhadap diskursus kebahasaan. Dari sekian karyanya, tiga karya konsen dalam aspek kebahasaan, yaitu Al-Bulghah fí Ushûl al-Lughah, Luff al-Qamâth, Al-'Ilm al-Khifâq min 'Ilm al-Isyqâq. Ketiganya diulas lengkap dalam artikel Abd al-Majîd Nadîm, Shiddîq $\underline{H}$ asan Khân al-Qannûjî wa Juhûduh al-Lughawiyyah, (Lahore: University of Punjab, t.t.), hlm. 38-53.

${ }^{45}$ Masing-masing lihat Hasan Khân, Fath al-Bayân fî Maqâshid al-Qur'ân, juz 3, hlm. 10, 15, 21, dan 22.

${ }^{46}$ Lihat, Ibid., juz 3, hlm. 16, 17, 19, dan 25.

47 Lihat, Ibid., juz 3, hlm. 11 dan 23.
} 
kembali, sementara epistemologi burhânî mencoba merespons dengan berkompromi terhadap pembaharuan atau modernitas. ${ }^{48}$

Cukup jelas al-Dulaymî memaparkan upaya Hasan Khân mencapai makna substansial al-Qur'an (maqâshid al-Qur'ân) dalam kitabnya. Menurut al-Dulaymî, itu bisa dilihat dari orientasi metodis Hasan Khân, yakni menafsirkan al-Qur'an dengan al-Qur'an, al-Qur'an dengan hadis, al-Qur'an dengan perkataan sahabat-tabiin, menafsirkan al-Qur'an secara kebahasaan, dan juga secara nalar, ${ }^{49}$ meskipun yang terakhir ini adalah nalar deduktif. Semua itu bisa kita tilik dalam penafsiran surah al-Nisâ' [4]: 1-5 di atas. Kemurnian penafsiran dipandang Hasan Khân sebagai landasan metodologis untuk mencapai makna autentik. Keterpeliharaan dari subjektivitas menjadi semacam manhaj yang dengannya Hasan Khân mencoba menyelami bagian paling inti dari al-Qur'an. Dalam konteks ini, barangkali kita melihat keterkungkungan metodis, tetapi kita perlu memahami bahwa semua itu tidak lepas dari epistemologi yang Hasan Khân gunakan, yaitu epistemologi bayânî. Temuan Dulaymî memberi kita sinyalemen bahwa, upaya Hasan Khân mencapai maqâshid al-Qur'an yang dimaksudkannya ia tempuh secara normatif, tidak secara kritik realitas. Suatu makna ia anggap otoritatif bilamana riwayatnya valid, bukan sebab faktor eksternal apa pun, seperti sejauh mana al-Qur'an mampu menjawab tantangan realitas universal.

Epistemologi Hasan Khân dalam menemukan maqâshid al-Qur'ân sarat akan epistemologi bayânî. Metode yang dipakainya masih konvensional, tetapi tidak sektarian seperti tafsir abad pertengahan yang memiliki kecenderungan tertentu. Bahwa setiap penafsiran merupakan respons terhadap realitas adalah sesuatu yang benar adanya, tetapi realitas dimaksud tidak selalu perihal problem kehidupan. Jika realitas tersebut diibaratkan seorang musuh, maka respons terhadapnya tidak melulu berupa perlawanan ke luar (eksternal), melainkan juga pembentengan diri (internal). Penafsiran Hasan Khân tergolong kategori terakhir ini. Ia tidak punya kepentingan sektarian tertentu, untuk mengafirmasi ideologi mereka. Tidak pula merespons problematika realitas spesifik hingga memerlukan seperangkat metodis modern. Yang dilakukan Hasan Khân ialah merevitalisasi nilai keislaman dengan berhaluan terhadap segala yang diajarkan al-Qur'an. Kendati pada dasarnya penarikan makna senantiasa terkait erat dengan teori penafsiran, seperti dikatakan oleh Ahmad Taufik, ${ }^{50}$ namun penarikan makna substansial (maqâsshid al-Qur'ân) Hasan Khân

\footnotetext{
${ }^{48}$ Seperti telah penulis kemukakan di awal, kolonialisme memorakporandakan Kerajaan Mughal, dan Hasan Khân merupakan satu dari sekian cendekiawan yang berusaha mengembalikan kemurnian Islam dari khurafat, takhayul, dan sejenisnya. Sementara modernis pembaharu berusaha merekonsiliasi kepercayaan Islam dengan nilai modern seperti demokrasi, hak asasi, nasionalisme, rasionalitas, sains, kesetaraan dan kemajuan. Mereka menuntut adanya kebutuhan untuk reinterpretasi serta reaktualisasi prinsip-prinsip ideal Islam dalam rangka menyusun formula baru tentang tantangan politik, sains, dan kebudayaan hidup modern. Maka ditempuhlah reformasi (ishlâh $\underline{\text { ), }}$ pembaharuan (tajdîd) dan ijtihad, sebagai jalan menuju keselarasan Islam dengan modernitas. Kabalikan mereka ialah tradisionalis, yaitu aliran yang menjadikan al-Qur'an, hadis, dan ketetapan ulama salaf sebagai pegangan, dan ketimbang pembaharuan, mereka lebih konsen terhadap kemurnian Islam. Lihat, Tauseef Ahmad Parray, "Islamic Modernist and Reformist Thought: A Study of the Contribution of Sir Sayyid and Muhammad Iqbal," World Journal of Islamic History and Civilization, vol. 1, no. 2, (2011), hlm. 79-80. Hasan Khân termasuk dalam golongan tradisionalis ini.

${ }^{49}$ Dulaymî, Shiddîq Hasan Khân al-Qannûjî̀; Juhûduh fî Tafsîrih, hlm. 133-34.

50 Ahmad Taufik, "Hubungan Antarumat Beragama (Studi Kritis Metodologi Penafsiran Tekstual)," Journal of Qur'ân and Hadîts Studies, vol. 3, no. 2, (Desember 2014), hlm. 145.
} 
berpatokan terhadap teori tafsir konvensional juga, tidak dengan teori hermeutika modern.Oleh karena itu perangkat metodisnya pun lebih sederhana, maka demikian pun epistemologinya.

Hasan Khân hidup di abad ke-19. Itu artinya, jika kategorisasi periodik perkembangan tafsir meletakkan abad ke-18 sebagai abad modern dengan munculnya tokoh pembaharu seperti Sayyid Ahmad Khân yang sudah disinggung sebelumnya, maka Hasan Khân hidup di zaman modern. ${ }^{1}$ Tetapi, jika periodisasi ditinjau secara epistemik, maka Hasan Khân termasuk mufasir yang menggunakan epistemologi bayânî.Di sini kita melihat ketidakselarasan antara masa dengan metode, antara realitas dengan pisau analisias mufasir, dalam hal ini Hasan Khân. Dengan kata lain, kita bisa membuat ilustrasi skematis bahwa epistemologi menentukan sepenuhnya hasil suatu penafsiran. Berbeda dengan itu, masa hidup mufasir sama sekali tidak berperan menentukan hasil tafsirannya, sebab mufasir berjalan dalam rel epistemologisnya. Tetapi penting digarisbawahi, bahwa masa memiliki andil besar atas lahirnya epistemologi. Kompleksitas realitas hidup yang dinamis menjadi titik tolak dari dinamika epistemologi itu sendiri.Tidak dapat dipungkiri bahwa perjalanan nalar bayânî menjadi burhânî secara historis berkaitan erat dengan kompleksitas kehidupan, dan tanpanya dinamika epistemologi adalah kemustahilan.

Kausalitas masa mufasir dengan konstruksi epistemologis yang dipakainya pada akhirnya menjadi penentu dari konsep ontis maqâshid al-Qur'ân menurut Hasan Khân. Dalam surah al-Nisâ' [4]: 1-5 di atas, kita melihat Hasan Khân menguraikan maqâshid dengan epistemologi bayânî, tetapi pada saat yang bersamaan kita berhadapan dengan realitas bahwa Hasan Khân hidup di era modern secara periodik dunia penafsiran. Jalin-berjalin yang rumit itu dalam konteks epistemologi Hasan Khân perihal maqâshid al-Qur'ân dalam tafsirnya, Fath al-Bayân fî Maqâshid al-Qur'ân ialah: bayânî sebagai pondasi epistemis, era reformatif nalar kuasi-ideologis, dan pragmatisme-cum-Koherensi.

\section{Implikasi Konsep Maqâshid al-Qur'ân Hasan Khân}

Bagian yang tidak kalah penting dalam mengulas konsep maqâshid al-Qur'ân menurut Hasan Khân setelah sisi ontologis dan epistemologis ialah sisi aksiologisnya. Bagian terakhir dalam kostruksi filosofis ini mengulas pertanyaan penting tentang 'apakah yang baik atau bagus'. ${ }^{52}$ Secara etimologis, aksiologi berasal dari bahasa Yunani 'axios' yang berarti nilai dan 'logos' yang bermakna teori. Aksiologi dikenal sebagai teori tentang nilai-kegunaan pengetahuan yang telah diperoleh. Ia terbagi ke dalam tiga elemen, yakni tindakan moral

\footnotetext{
${ }^{51}$ Dalam peradaban Barat, zaman modern dimulai sejak abad ke-15 hingga abad ke-19. Penentuan abad ke-18 tersebut bukan mengacu pada peradaban Barat, melainkan dari muculnya geliat pembaharuan Islam. Lihat, Abdul Mustaqim, Dinamika Sejarah Tafsir al-Qur'an; Studi Aliran-aliran Tafsir dari Periode Klasik, Pertengahan hingga Modern-Kontemporer, cet. ke-2, (Yogyakarta: Idea Press, 2016), hlm. 147. Syukron Affani bahkan meletakkan abad ke-20 sebagai awal mula zaman modern dalam perkembangan sejarah al-Qur'an, yang ditandai dengan digalakkannya reformasi apologis, reformasi progresif, dan reformasi moderat. Selengkapnya lihat, Syukron Affani, Tafsir al-Qur'an dalam Sejarah Perkembangannya (Jakarta: Kencana, 2019), hlm. 9-10.

52 Muhammad Noor Syam dalam Tri Suminar, "Tinjauan Filsafati (Ontologi-Epistemologi-Aksiologi) Manajemen Pembelajaran Berbasis Teori Sibernetik," journal.unnes.ac.id/nju/index.php/edukasi/article/download/961/898, (diakses pada 26 April 2019), hlm. 4.
} 
yang melahirkan etika (moral conduct), ekspresi keindahan (esthetic expression), dan kehidupan sosial politik (sosio-political life). ${ }^{53}$ Konotasi nilai dimaksud ialah nilai kegunaan, ${ }^{54}$ implikasi dari konstruksi pemikiran tersebut, serta hakikat nilai itu sendiri. Oleh karena maqâshid al-Qur'ân—atau bahkan seluruh diskursus ilmu-ilmu al-Qur'an-senantiasa berkembang lintas zaman dengan dinamika yang kompleks, nilai di dalamnya juga tidak pernah statis. Dan dalam perkembangan itu setiap pemikiran memiliki nilainya tersendiri, yang bisa kita telaah untuk memproyeksikan sisi dinamis pemikiran tersebut. Itulah yang hendak kita aplikasikan terhadap konsep maqâshid al-Qur'ân dalam tafsir Hasan Khân.

Perhatian aksiologi ialah hal-ihwal baik dan buruk, benar dan salah, serta cara (means) dan sasaran (objective). Sedangkan pembagiannya seperti tiga poin yang sudah disinggung sebelumnya. Cara kerja nilai dalam aksiologi juga mencakup teori nilai intuitif, nilai rasional, nilai alamiah, dan nilai emotif. Dalam semua teori tersebut, nilai mengejawantah ke dalam persoalan objektif atau subjektif, absolut atau abadi, etika, dan estetika. Atas semua itu, kita harus menyadari bahwa aspek kegunaannya adalah sebagai kumpulan teori, pandangan hidup, dan sebagai metodologi. ${ }^{55}$ Selain itu nilai juga dipakai sebagai kata kerja dalam ekspresi menilai, memberi nilai, dan dinilai. Menilai setara dengan mengevaluasi, sama-sama berfungsi menilai perbuatan. Oleh Dewey, menilai dibedakan menjadi dua antara berarti menghargai dan mengevaluasi. ${ }^{56}$ Aspek aksiologis dengan demikian mengulas nilai konsep maqâshid al-Qur'ân Hasan Khân, mengulas cakupan teori nilai di dalamnya, baik intuitif maupun ilmiah dan lainnya, serta sisi objektif-subjektif dalam konteks mengapresiasi maupun mengevaluasinya.

Surah al-Nisâ' [4]: 1-5 barangkali terlalu sederhana untuk ditelaah secara aksiologis, tetapi konstruksi ontologis dan epistemologisnya telah penulis uraikan dalam sub-bab sebelumnya. Dari itu kita bisa memahami pendekatan Hasan Khân untuk menafsirkan alQur'an begitu kentara normatif. Otoritas riwayat sebagai titik tolak penafsirannya, rasionalitas (ra'y) yang teralienasi sebab pengarusutamaan tafsir, purifikasi tafsir demi tersingkapnya maqâshid yang dianggap autentik, serta metode analitis (tahlîilî) memiliki implikasi signifikan terhadap diskursus maqâshid al-Qur'ân itu sendiri. Penulis mengklasifikasi tiga hal yang dapat kita pahami sebagai aspek implikatif dari konsep maqâshid al-Qur'ân-nya Hasan Khân, yaitu dekonstruksi relativitas, rigiditas tafsir, dan atomistisasi Maqâshid al-Qur'ân.

\section{PENUTUP}

Dalam upaya mencapai maqâshid, Hasan Khân berpatokan pada rel epistemis konvensional yang tercakup dalam tiga poin utama. Pertama, bayânî sebagai pondasi epistemis. Dalam menafsirkan surah al-Nisâ' [4]: 1-5, Hasan Khân menjadikan riwayat sebagai otoritas. Kedua, era reformatif nalar kuasi-ideologis. Bagian ini bisa diselisik dari bangunan epistemis yang dipakai Hasan Khân, di tengah realitas bahwa ia hidup di era

\footnotetext{
${ }^{53}$ Aceng Rahmat, Conny Semiawan, dkk, Filsafat Ilmu Lanjutan, cet. ke-1, (Jakarta: Kencana, 2011), hlm. 154-55.

54 Totok Wahyu Abadi, “Aksiologi: Antara Etika, Moral, dan Estetika," Kanal Jurnal Ilmu Komunikasi, vol. 4, no. 2, (Maret 2016), hlm. 189.

55 Rudy Haryanto, "Review Filsafat Ilmu; Dasar Aksiologi," https://www.researchgate.net/publication/324600874, (diakses pada 25 April 2019), hlm. 3-6.

${ }^{56}$ Rahmat, Conny Semiawan, dkk, Filsafat Ilmu Lanjutan, hlm. 155-56.
} 
modern. Kendati demikian, Hasan Khân tidak memiliki kepentingan sektarian tertentu. Ia sekadar berusaha mengelaborasi semua pendapat untuk ditentukan yang paling sahih. Ketiga, pragmatisme-cum-koherensi, yakni pragmatis semi koheren. Validitas penafsiran Hasan Khân dapat diselisik melalui teori tersebut. Sintesis pragmatisme-cum-koherensi memosisikan pemikiran Hasan Khân sebagai sesuatu yang unik, sebab tentatifitas penafsiran tidak lagi terjebak dalam analisis yang dangkal. Hal itu dapat dilihat bahwa ketika menafsirkan surah al-Nisâ' [4]: 1-5, ia menelisik makna secara intertekstualitas. Konsep maqâshid al-Qur'ân menurut Hasan Khân, yang telah penulis uraikan melalui penafsirannya terhadap surah al-Nisâ' [4]: 1-5, memiliki implikasi yang cukup menghentak disiplin penafsiran al-Qur'an. Dengan epistemologi konvensional yang dipakainya, sedikitnya ada tiga poin yang menjadi implikasinya, yakni dekonstruksi relativitas, rigiditas tafsir, dan atomistisasi maqâshid al-Qur'ân. Sungguhpun demikian, kita tidak bisa menegasikan kenyataan bahwa pemikiran Hasan Khân tentang maqâshid al-Qur'ân telah mewarnai diskursus tersebut. Untuk memahami konsep maqâshid dalam pandangan Hasan Khân, maka kita mesti memahami berdasarkan konstruksi epistemologis yang dipakai Hasan Khân sendiri.

\section{DAFTAR PUSTAKA}

Âbâdî, Muhammad Abû al-Layts al-Khayr. (ed.). Al-Wahyy wa al-'Ulûm fî al-Qarn al-Wâhid wa al-'Isyrîna. Cet. Ke-1. Malaysia: IIUM Press. 2011.

Abadi, Totok Wahyu. "Aksiologi: Antara Etika, Moral, dan Estetika." Kanal Jurnal Ilmu Komunikasi. Vol. 4. No. 2. Maret 2016.

Affani, Syukron. Tafsir al-Qur'an dalam Sejarah Perkembangannya. Pamekasan: Al-Qadiry Publishing. 2015.

Auda, Jasser. Maqâshid al-Syarî́ah Dalîl li al-Mubtadiîn. Cet. Ke-1. Washington: Ma'had al'Âlamî li al-Fikr al-Islâmî. 2011.

Bahrum. "Ontologis, Epistemologi dan Aksiologi." Sulesana.Vol. 8.No. 2. 2013.

Dîn, Muhammad al-Râzî Fakhr al-. Tafsîr al-Fakhr al-Râzî al-Musytahir bi al-Tafsîr al-Kabîr wa Mafâtîh al-Ghayb. Beirut: Dar al-Fikr. 1981.

Dulaymî, Muwaffaq 'Abd al-Razzâq al-. Shiddîq Hasan Khân al-Qanûjî̀; Juhûduh fî Tafsîrih Fath al-Bayân fî Maqâshid al-Qur'ân. Cet. ke-1. Riyadh: Al-Tawbah. 2014.

Fikriyati, Ulya. "Maqâshid al-Qur'ân dan Deradikalisasi Penafsiran dalam Konteks Keindonesiaan." Islamica: Jurnal Studi Keislaman. Vol. 9. No. 1. September 2014.

Fikriyati, Ulya dan Ahmad Fawaid, "Pop-Tafsir on Indonesian YouTube Channel: Emergence, Discourse, and Contestations," Proceeding AICIS 2019, Oktober.

Halalî, 'Abd al-Rahmmân. "Muqârabât Maqâshid al-Qur'ân al-Karîm; Dirâsah Târikhiyyah.” AlTajdîd. Vol. 20. No. 39. 2016.

Hâmidî, 'Abd al-Karîm. Maqâshid al-Qur'ân min Tasyrî̀ al-Ahkâm. Cet. ke-1. Beirut: Dâr Ibn Hazm. 2008.

Hamûdî, Muhammad Mahdi 'Alî al-. Al-Qannûjî wa Arâ'uh al-Tafsîriyyah 'alâDhaw' Aqwâl Aimmat al-Tafsîr. Sudan: Wizârat al-Ta'lîm al-'Âlî wa al-Bahts al-'Ilmi. 2015.

Haryanto, Rudy. "Review Filsafat Ilmu; Dasar Aksiologi." https://www.researchgate.net/publication/324600874 (diakses pada 25 April 2019). 
Hûjah, Muhammad Habîb ibn al-. Maqâshid al-Syarî́ah al-Islâmiyyah li Syaikh al-Imâm alAkbar Muhammad Thâhir ibn 'Âsyûr. Jilid 3. Qatar: Thab'ah Wizârat al-Awqâf wa alSyu'ûn al-Islâmiyyah. 2004.

Khân, Shiddîq Hasan. Fath al-Bayân fi Maqâshid al-Qur'ân; Tafsîr Salafîy Atsarîy Khâlin min alIsrấîliyyât wa al-Jadaliyyât al-Madzhabiyyah wa al-Kalâmiyyah Yughnî 'an Jamî'i alTafâsîr wa Lâ Tughnî Jamî'uha 'Anhu. Beirut: Al-Maktabah al-'Ashriyyah. T.t.

Mustaqim, Abdul. Dinamika Sejarah Tafsir al-Qur'an; Studi Aliran-aliran Tafsir dari Periode Klasik, Pertengahan hingga Modern-Kontemporer. Cet. ke-2. Yogyakarta: Idea Press. 2016.

Mustaqim, Abdul. Epistemologi Tafsir Kontemporer. Cet. ke-1. Yogyakarta: LKiS. 2010.

Mustaqim, Abdul. Metode Penelitian al-Qur'an dan Tafsir. Cet. ke-1. Yogyakarta: Idea Press. 2015.

Nadîm, Abd al-Majî̀d. Shiddîq Hasan Khân al-Qannûjî wa Juhûduh al-Lughawiyyah. Lahore: University of Punjab. T.t.

Parray, Tauseef Ahmad. "Islamic Modernist and Reformist Thought: A Study of the Contribution of Sir Sayyid and Muhammad Iqbal," World Journal of Islamic History and Civilization. Vol. 1.No. 2. 2011.

Poespowardojo, T. M. Soerjanto dan Alexander Seran.Filsafat Ilmu Pengetahuan: Hakikat Ilmu Pengetahuan, Kritik Terhadap Visi Positivisme Logis, serta Implikasinya. Cet. Ke-2. Jakarta: Kompas. 2015.

Rahmat, Aceng. Conny Semiawan, dkk. Filsafat Ilmu Lanjutan. Cet. Ke-1. Jakarta: Kencana. 2011.

Raysûnî, Ahmad al-. Madkhal ilâ Maqâshid al-Syarî̀ah. Kairo: Dâr al-Kalimah li al-Nasyr wa alTawzî̀. 2010.

Setiawan, M. Nur Kholis. “Al-Qur'an dalam Kesarjanaan Klasik dan Kontemporer; Keniscayaan Geisteswissenschaften." Jurnal Studi al-Qur'an. Vol. 1.No. 1.2006.

Soleh, Khudori. Filsafat Islam dari Klasik hingga Kontemporer. Cet. Ke-1. Yogyakarta: Ar-Ruzz Media. 2016.

Suminar, Tri. "Tinjauan Filsafati (Ontologi-Epistemologi-Aksiologi) Manajemen Pembelajaran Teori Sibernetik," journal.unnes.ac.id/nju/index.php/edukasi/article/download/961/898. Diakses pada 26 April 2019.

Syahza, Almasdi. "Filsafat Ilmu: Ontologis, Epistemologi, Aksiologi," dalam http://almasdi.unri.ac.id (diakses pada 6 April 2019).

Taufik, Ahmad. "Hubungan Antarumat Beragama (Studi Kritis Metodologi Penafsiran Tekstual)." Journal of Qur'ân and Hadîts Studies. Vol. 3.No. 2. Desember 2014.

Thabarî, Muhammad ibn Jarîr al-. Jâmi' al-Bayân 'an Ta'wîl Âyi al-Qur'ân. Cet. Ke-2. Kairo: Makatabah Ibn Taimiyah. T.t.

Wadud, Amina. Qur'an and Women; Rereading the Sacred Text from a Woman's Perspective. New York: Oxford University Press. 1999.

Wijaya, Aksin. Nalar Kritis Epistemologi Islam. Cet. Ke-2. Yogyakarta: Teras. 2013. 